\title{
The U.S. Role and Policy in Central Asia: Energy and Beyond
}

\author{
A.K.M Iftekharul Islam*
}

\section{Introduction}

A significant geopolitical consequence of the demise of the Soviet Union ${ }^{1}$ in the international arena is the rise of intense political and commercial competition for control of the vast energy resources of the newly independent and vulnerable states of the Caucasus and Central Asia. These energy resources and, in particular, the oil and natural gas deposits have now become the apple of discord in Central Asia introducing a new chapter in the Great Game of control over Eurasia (Hill 1997: 200). The region has great energy potential and is strategically important. The United States has varied and at times competing interests in Central Asia. In the past few years, real and present dangers to the U.S. national security especially Islamist terrorism and threats to the energy supply, have affected the U.S. policy in Central Asia. The region, which includes the five post-Soviet states of Kazakhstan, Kyrgyzstan, Tajikistan, Turkmenistan, and Uzbekistan, as well as Afghanistan and the Caspian basin, plays an important part in the U.S. global strategy in view of its proximity to Russia, China, India, Pakistan, Iran, and other key regional actors. No less important are its ethno-religious composition and vast deposits of oil, gas, coal, and uranium. Literally, the U.S. interests in Central Asia can be summarized in three simple words: security, energy, and democracy. Moreover, a key U.S. national security concern is the

\footnotetext{
${ }^{*}$ Lecturer, Dept. of Islamic History and Culture, University of Dhaka
}

1. The Union of Soviet Socialist Republics (USSR) informally known as the Soviet Union was a constitutionally socialist state that existed on the territory of most of the former Russian Empire in Eurasia between 1922 and 1991. In the late 1980s the last Soviet leader Mikhail Gorbachev tried to reform the state with his policies of Perestroika and Glasnost, but the Soviet Union ultimately collapsed and was formally dissolved in December 1991 after the abortive August coup attempt. 
diversification of energy sources and the Caspian region is a significant alternative source of fossil fuels. In this article a critical analysis will be attempted on the U.S. policy and role in central Asia.

\section{Geopolitical Importance}

From a geopolitical point of view, Central Asia has always been important (Gray 1977: 179). From the middle to the end of the 19th century, while the region was part of the Russian Empire, the oil-bearing areas of Baku were producing half of the world's oil supplies (Tolf 1976:50). In World War II, during his campaign against Russia, Hitler tried to capture Baku and the Caucasian oil fields as part of his strategy for world domination. However, after the war, the Soviets retained these areas as reserves, choosing to exploit oil deposits on Russian soil, in Tatarstan and Siberia (Yergin 1991:62). Following the collapse of communism, the ex-Soviet republics of Central Asia, especially Azerbaijan and Kazakhstan, have been trying to exploit their natural resources, since they consider oil to be the prime means of securing their economic and political independence. According to the estimates of geologists, the oil deposits of the Caspian Sea may not be quantitatively comparable to the deposits of the Persian Gulf, but they are still considered of excellent quality and able to provide a significant alternative source of energy in the 21st century (Ebel 1996:116). In particular, it is estimated that the entire Caspian Sea is a basin full of oil and natural gas, starting from Azerbaijan and continuing to the opposite shore in the territory of Kazakhstan and Turkmenistan. These deposits take on enormous importance because of the expected exhaustion of the deposits of Alaska and the North Sea by the year 2020.

\section{Policy Overview}

The five states of Central Asia present special challenges and paradoxes in the international arena. While possessing great natural resources, they ranked among the poorest and least-developed of the former Soviet republics at the time of independence. Despite its 
Silk Road ${ }^{2}$ heritage and position at a historic crossroad of European and Asian civilizations, the region was the most isolated in the USSR at the time that empire broke apart. Proud founders of great Islamic centers of faith and scholarship whose ranks included the great physician and philosopher, Ibn Sina ${ }^{3}$, and the astronomer Ulu Beg, the Central Asians are today challenged to define anew the relationship between religion and the state after more than 70 years of enforced atheism. In engaging these new nations, the United States' challenge has been to promote modern, tolerant states and societies which can work productively with the country in support of shared interests. For the U.S. what is needed in the Central Asia is a policy that allows the country to continue to diversify its energy supplies, station its military forces close to the most immediate threats, and create a lasting and deep impact by promoting democratic and free-market values in an area that is still undergoing political and economic development. James Collins, a noted Congressman has defined in a speech the following U.S. objectives in the New Independent States (NIS) which the country has tailored to meet the specific needs of the rich and complex region of Central Asia:

a. Support for the independence, sovereignty and security of each of the Central Asian States;

2. The Silk Road (German: Seidenstraße) (or Silk Routes) is an extensive interconnected network of trade routes across the Asian continent connecting East, South, and Western Asia with the Mediterranean world, as well as North and Northeast Africa and Europe. The Silk Road gets its name from the lucrative Chinese silk trade. The term "Seidenstraße" (literally "Silk Road") was coined retrospectively by the German geographer Ferdinand von Richthofen in 1877 and has since found its way into general usage.

3. Abū 'Alī al-Husayn ibn 'Abd Allāh ibn Sīnā', known as Abū Alī Sīnā or, more commonly, Ibn Sīnā but most commonly known in English by his Latinized name Avicenna ( 980 - 1037) was a polymath of Persian origin and the foremost physician and philosopher of his time. He was also an astronomer, chemist, geologist, Hafiz, Islamic psychologist, Islamic scholar, Islamic theologian, logician, paleontologist, mathematician, Maktab teacher, physicist, poet, and scientist. His most famous works are The Book of Healing, a vast philosophical and scientific encyclopaedia, and The Canon of Medicine, which was a standard medical text at many medieval universities. The Canon of Medicine was used as a text-book in the universities of Montpellier and Louvain as late as 1650 . 
b. Assistance in the establishment of free-market economies and democratic governments committed to equal opportunity and human rights for their citizens;

c. Integration of these states into the world community of political and financial institutions, as well as their participation in the Euro-Atlantic security dialogue and cooperative programs;

d. Encouragement of these states to pursue peaceful relations among themselves and with their neighbors, to seek new avenues for regional cooperation and to resolve local conflicts with international mediation;

e. Prevention of any trafficking in weapons of mass destruction or their elements across this region or its borders. The departure of the last nuclear warhead from Kazakhstan in 1995 was a significant achievement in support of non-proliferation;

f. Enhancement of the U.S. commercial interests and the expansion and diversification of global energy supplies.

This agenda is complex and demanding, but the message is that the U.S.A. is making progress throughout Central Asia in advancing it. The essence of this newly regenerated geopolitical game in Central Asia is twofold: first, control of production of the oil and gas, and second, control of the pipelines which will transfer the oil to the western markets. Here one question arises why is the U.S.A. attracted to this region. The answer may be that the Caspian Sea basin has attracted the US interest for the following reasons:

1. The oil of this region is considered to be of good quality.

2. The biggest part of this oil is intended for export, since the needs of the producing countries are relatively low and are expected to remain low.

3. The fact that the countries of the region lack the capital and the technology to proceed independently to the development of these oilfields offers American companies, such as Chevron, considerable investment opportunities. 


\section{Hydrocarbon Reserves}

The hydrocarbon reserves of Central Asia are concentrated mainly in the Caspian region. Azerbaijan is therefore a principal actor, despite its location in the Caucasus. The bulk of Central Asian-Caspian hydrocarbons is located in Kazakhstan, Azerbaijan, Uzbekistan, and Turkmenistan. Both Tajikistan and the Kyrgyz Republic have limited reserves of oil and gas in amounts that have not warranted much attention from foreign investors. The details of oil and gas reserves of the region are discussed below.

\section{Oil}

Table: 1- Oil reserves in the Caspian Sea Region; (Billions of barrels)

\begin{tabular}{|l|l|l|l|}
\hline Country & Proven & Possible & Total \\
\hline Azerbaijan & 7 & 32 & 39 \\
\hline Iran & 0.1 & 15 & 15.1 \\
\hline Kazakhstan & $9-40$ & 92 & $101-132$ \\
\hline Russia* & 0.3 & 7 & 7.3 \\
\hline Turkmenistan & $0.55-1.7$ & 38 & $38.55-39.7$ \\
\hline Uzbekistan & $0.3-0.59$ & 2 & $2.3-2.59$ \\
\hline Total & $17.2-49.3$ & 186 & $203.2-235.7$ \\
\hline
\end{tabular}

*Includes only Caspean area oil production

Note: The Caspian Sea Region's proven oil reserves of between 17.2 billion and 49.3 billion barrels are comparable to Qatar's oil reserves on the low end and the U.S. reserves on the high end.

Source: U.S. Department of Energy, Energy Information Administration, "Caspian Sea Region: Survey of Key Oil and Gas Statistics and Forecasts," July 2006, at www.eia.doe.gov/emeu/cabs/ Caspian/images/ caspian_balances.pdf (November 9, 2006). 
The table, which shows proven and possible oil reserves by country, demonstrates the region's largest oil deposits. The three largest regional oil projects are located in Kazakhstan and Azerbaijan. These three projects are in the Tengiz and Karachaganak fields in Kazakhstan and the Azeri-Chirag-Guneshli (deep-water) field in Azerbaijan. Each project includes Western oil majors as shareholders.

- Tengiz: Tengiz Chevroil (50 percent Chevron Texaco, 25 percent ExxonMobil, 20 percent Kazakh government).

- Karachaganak: Karachaganak Consortium (32.5 percent each Agip and British Gas, 20 percent Texaco, 15 percent LUKoil).

- Azeri-Chirag-Guneshli: Azerbaijan International Oil Company (operated by BP; other shareholders are Unocal, LUKoil, Statoil, ExxonMobil, TPAO, Devon Energy, Itochu, Delta Hess and SOCAR). Potential offshore reserves of Turkmen oil in the Caspian Sea have yet to be explored or developed because of disputes between Turkmenistan, Azerbaijan, and Iran over border delineation in the southern portion of the sea.

\section{Oil Transit}

Existing oil pipelines in Central Asia include the following:

- The Baku-Tbilisi-Ceyhan pipeline (BTC), with a capacity of over 1 million barrels per day, which runs from the Azerbaijani coast of the Caspian Sea to the Mediterranean coast of Turkey. Its major shareholders form a consortium that includes British Petroleum (BP), SOCAR, Chevron, Statoil, Total, ENI, Itochu, ConocoPhillips, and ExxonMobil.

- The "Northern" (Baku-Novorossiysk) and "Western" (BakuSupsa) early Oil Pipelines, with capacities of 100,000 and 115,000 barrels per day, respectively. These begin on the Azerbaijani coast of the Caspian Sea and travel to the Russian port of Novorossiysk and the Georgian Black Sea port at Supsa.

- A newly signed barge route agreement between Kazakhstan and Azerbaijan to supply 10 million tons (approximately 733 
million barrels) of Kazakhstani oil per year initially to the Baku-Tbilisi-Ceyhan pipeline.

- Atyrau-Samara, a Russian owned pipeline, which extends from Atyrau, Kazakhstan, to Samara, Russia. Its current capacity is $300,000 \mathrm{bbl} /$ day, but Russia has pledged to increase its capacity to $500,000 \mathrm{bbl} / \mathrm{day}$.

\section{Caspian Sea Region Oil Pipelines}

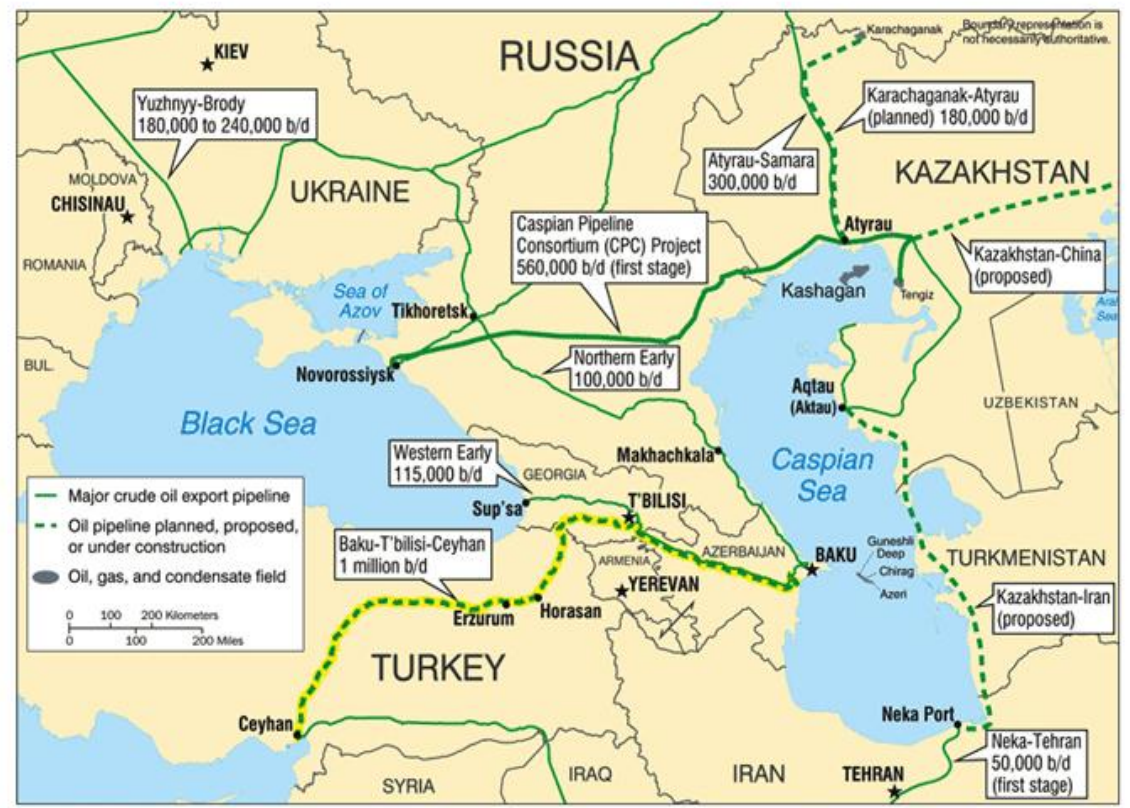

- The Kazakhstan-China pipeline, the first stage of which connects the Kazakh oil fields of Aktobe to the Kazakh oil hub of Atyrau is already complete. The second stage, which will run from Atasu (northwestern Kazakhstan) to Alashkanou (Xinjiang, China) and will cost an estimated $\$ 850$ million and have initial and eventual capacities of 200,000 bbl/d and $400,000 \mathrm{bbl} / \mathrm{d}$, respectively, is under construction.

- The Caspian Pipeline Consortium (CPC), which connects Kazakh oil deposits to the Russian port of Novorossiysk. It is owned and operated by Western companies, as well as the Russian, Kazakh, and Omani government owned companies. A 
pipeline that runs from the Shymkent refinery in Kazakhstan to Chardzhou, Turkmenistan (via Uzbekistan).

- An oil swap agreement between Turkmenistan and Iran whereby Turkmen oil is delivered to the Iranian port of Neka via barge.

It is estimated that the oil fields of Central Asia are capable of producing about 4 million barrels per day in 2018, roughly equivalent to the daily production levels of Iraq and Kuwait combined. Possible future oil pipeline projects include the Central Asia Oil Pipeline (CAOP) and the Kazakhstan-China pipeline. Finally, in December 2002, the governments of Turkmenistan, Afghanistan, and Pakistan signed a 'Memorandum of Understanding' to construct the Central Asia Oil Pipeline, which would bring Uzbek and Turkmen oil to Gwadar, Pakistan, on the Arabian Sea. However, this project has been delayed by continued instability in Afghanistan.

\section{Natural Gas}

The Central Asian countries with largest reserves of natural gas are Turkmenistan and Uzbekistan, although there are considerable amounts of gas in Kazakhstan (particularly the Karachaganak field in western Kazakhstan) and Azerbaijan (Shah Deniz).

Table: 2- Natural Gas reserves in the Caspian Sea Region; (Trillion cubic feet)

\begin{tabular}{|l|l|l|l|}
\hline Country & Proven & Possible & Total \\
\hline Azerbaijan & 30 & 35 & 65 \\
\hline Iran & 0 & 11 & 11 \\
\hline Kazakhstan & 65 & 88 & 153 \\
\hline Russia* & N/A & N/A & N/A \\
\hline Turkmenistan & 71 & 159 & 230 \\
\hline Uzbekistan & 66 & 35 & 101 \\
\hline Total & 232 & 328 & 560 \\
\hline
\end{tabular}


Note: The Caspian Sea Region's proven natural gas reserves of 232 trillion cubic feet are comparable to Saudi Arabia's natural gas reserves.

Source: U.S. Department of Energy, Energy Information Administration, "Caspian Sea Region: Survey of Key Oil and Gas Statistics and Forecasts," July 2006, at www.eia.doe.gov/emeu/cabs/ Caspian/images/caspian_ balances.pdf (November 9, 2006)

\section{Natural Gas Transit}

Central Asian gas transit routes not controlled by Russia, are scarce and are currently limited to the as yet unfinished BakuTbilisi-Erzerum pipeline, from Azerbaijan to Turkey, and Korpedzhe-Kurt-Kui, which is short, extending only from Turkmenistan to Iran. Future projects are hindered by heightened political risk and an unfriendly investment climate. Other than Korpedzhe-Kurt-Kui, all Turkmen and Uzbek natural gas exports are controlled by Gazprom ${ }^{4}$, and almost all Turkmen gas is exported to Russia via Uzbekistan or to Ukraine via Russia. Existing gas pipelines include:

- The Central Asia-Center Pipeline, which routes Turkmen gas to Russia via Kazakhstan into Gazprom's system of gas pipelines. Its East and West branches have an annual capacity of 3.53 trillion cubic feet, and there are plans to expand capacity by 2012.

- Korpedzhe-Kurt-Kui is a joint project of the Turkmen and Iranian governments to bring Turkmen gas to Iran. It is the first non-Russian gas pipeline in Central Asia and has an annual capacity of close to 300 billion cubic feet (bcf).

- Tashkent-Bishkek-Almaty is Russian-owned and brings Uzbek gas to southern Kazakhstan. It is Uzbekistan's major gas export pipeline and is also used to deliver gas to Kyrgyzstan. Its capacity is approximately 777 bcf.

4. Gazprom is one of the world's largest energy companies. Its major business lines are geological exploration, production, transportation, storage, processing and marketing of hydrocarbons as well as generation and marketing of heat and electric power Gazprom's mission is to ensure maximally efficient and balanced gas supply to Russian customers and reliably fulfill long-term gas export contracts. 
Future gas transit projects include the Trans-Afghan Pipeline (TAP) and the South Caucasus (Baku-Tbilisi-Erzerum, or BTE) Pipeline. The TAP will bring gas from Turkmenistan through Afghanistan to Fazilka, a port on the Indian-Pakistani border. The governments of Turkmenistan, Afghanistan, and Pakistan signed a 'Memorandum of Understanding' in February of 2006 for construction of the pipeline, and it also has strong backing from India. American officials are promoting the TAP, which will be renamed TAPI when India signs on, as an alternative to the IranPakistan-India pipeline. However, instability in Afghanistan and questions surrounding the commercial viability of the project, which has a planned annual capacity of $1.1 \mathrm{bcf}$, have far delayed its implementation. The BTE is currently under construction. It will run parallel to the BTC oil pipeline from the Shah Deniz gas fields in Azerbaijan to Greece and presumably will then be linked to Nabucco, a planned gas pipeline to bring Central Asian and Caspian gas through Greece, Italy, and Austria. The BTE's planned initial capacity is $1.5 \mathrm{bcf} / \mathrm{yr}$, to be increased to $3 \mathrm{bcf} / \mathrm{yr}$ by 2017. Major shareholders include BP, Statoil, SOCAR, LukAgip, Nico (Iran), and Total.

The USA leads the world in oil consumption, with 17 million barrels a day in 2001. Of this quantity, 50\% is imported, so that dependence on oil imports is expected to rise steadily in the next. Even though the US government committees, examining the issue, have found that dependence on oil imports threatens the US national security, American oil policy has not changed radically with regards to imports. These findings have not led to the formation of a new oil policy which would aim at the progressive reduction of oil imports. They have, however, led the American Government to seek diversification of supply, to avoid dependence on a single supplier or team of suppliers. The addition of new exporters, such as Kazakhstan and Azerbaijan, to the already existing oil-producing and exporting countries provides more freedom of choice for importing countries such as the US, while it also helps to keep oil prices down (Ebel 1995:120). Within this framework, it may explain the American interest in the restructuring of the Russian oil industry as well as in participation in the development of oilfields in the Caspian Sea and the surrounding countries. These oil deposits constitute new sources of supply from 
countries outside the OPEC and are, for this reason, extremely important on the political as well as on the economic level. In this context, we can better understand the geopolitical and economic aims of the US in Central Asia. At the geopolitical level, the United States wants to help the countries of Central Asia to develop their oil and natural gas industries. According to the estimates of the American Government, this development will bring about economic growth and will help these countries move away from the Russian sphere of influence.

As far as the U.S. policy is concerned, the U.S. involvement with Kazakhstan and Azerbaijan has been successful. In both countries, western investment has been not only allowed, but facilitated by local governments, with a commensurate increase in per capita GDP and overall standards of living. Both countries are also now economically competitive in energy sectors on an international level. There are many political risks to doing business in Central Asia. As previously mentioned, property rights, transparency, and law enforcement are still in the process of development in these countries. Corruption is endemic, as are human rights violations. None of these issues deters Russian or Chinese investments, making competition in the area more difficult for Western firms that seek investment guarantees. Furthermore, Russia is making every effort to keep Western investments out of its former sphere of influence. Security, particularly in terms of Islamist terrorism and radicalism (the Islamic Movement of Turkestan, the global Hizb'ut Tahrir, Akramiyya of Uzbekistan, and other organizations), is a pressing issue for all of Central Asia's governments and may pose serious risks for potential investors in energy and vulnerable energy infrastructure. Despite these political vulnerabilities, investors and governments in the U.S., the United Kingdom, France, Italy, Russia, China, and the Middle East still seem eager to lay claim to the hydrocarbon resources of Central Asia. One of the most attractive features of Central Asian oil and gas is that there are deposits that have yet to be explored or developed, and the national governments are reliant on foreign investors to provide the capital to undertake such costly projects. Geopolitical consideration is another key concern as Central Asia continues to evolve as a highly 
important strategic area, especially for the U.S., Russia, China, Iran, and India. Political instability in other major oil and gas producing locations - the Middle East, Venezuela, and Nigeria-and increasing economic nationalism in Russia are also fueling the drive to claim a share of Central Asian resources.

For the last few years, the U.S. Government allowed huge grants for the developments of these states. At the economic level, the development of the oil industry of these countries means investment opportunities for the American construction and oil companies.

Table: 3

Total U.S. Government Assistance to Central Asia, 1992-2004

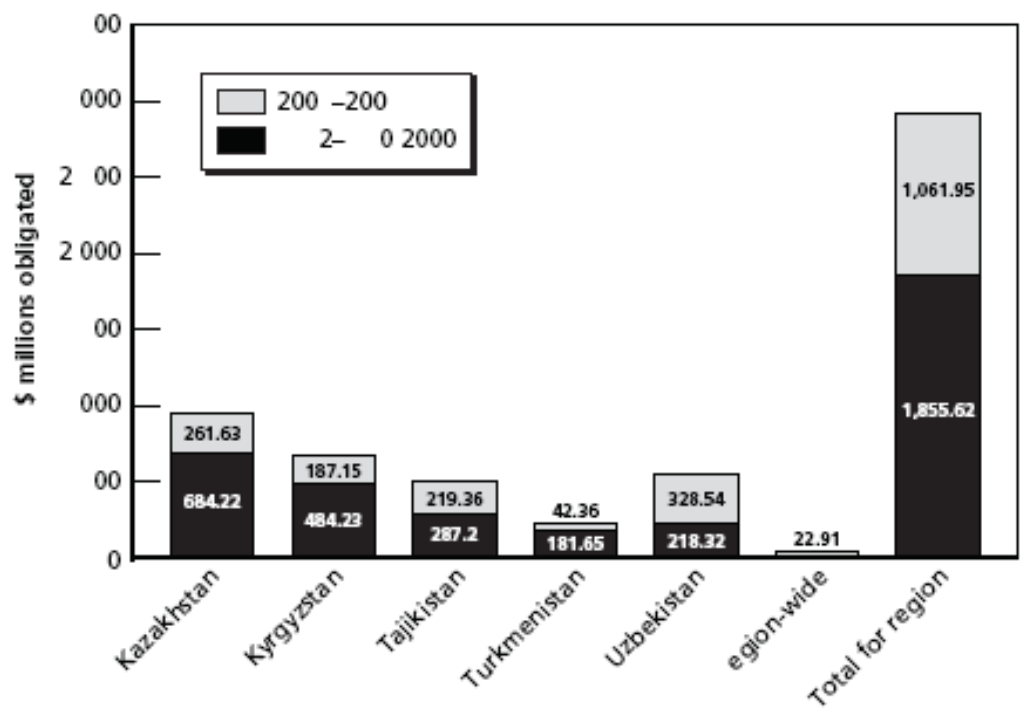

Source: U.S. Department of State 2004

Politically, the United States will be in a position to control these new important energy resources and diversify its own sources supply. American private companies have been supported by the US Government in at least two countries of Central Asia, namely, Kazakhstan and Azerbaijan. Other American political objectives include the containment of Iran and the reinforcement of Turkey's role in the region. The U.S. has not only blocked any pipeline route 
passing through Iran, but has also cancelled Iran's participation in the international consortium which has undertaken oil production in Azerbaijan (Forsythe 1996: 6).

However, even if the U.S. had the capacity to limit the presence of other large powers in the region, to do so would be unwise. First of all, the primary U.S. goals in the region are energy security and proximity to terrorist threats, not outright control. Limiting other powers in the region is unnecessary and would be a grave mistake, just as it was an error for the U.S. to support an oil and steel embargo on Japan in the 1930s, triggering Japanese expansion in the Pacific. The U.S. and other great powers share the goals of stability, economic development, and prevention of religious radicalization and terrorism. Rather than openly antagonizing China, Russia, or India over their involvement in Central Asia, the U.S. should pursue the benefits to be derived from regional cooperation. It is the policy of the United States to diversify world sources of oil, not only for itself but also for other oil importers. The idea reduced dependency on any particular region, thus decreasing the possibility that a political upheaval in one country/region will significantly affect oil supplies and possibly bring about a global economic crisis. The switch to new exporters outside the Organization of Petroleum Exporting Countries (OPEC) also helps keeping global oil prices down. Now here the addition of Caspian oil could weaken the (OPEC) monopoly, providing greater leverage over the pricing policies of Saudi Arabia and other OPEC countries, ultimately contributing to lower world oil prices. Moreover, American firms are among the world's largest oil producers, and their interests in developing and exporting Caspian energy resources neatly coincide with the U.S. desire to add to the world's sources of oil. Despite the unappealing nature of the region's authoritarian regimes, Chinese and Russian backing of these governments contributes to their short-term stability and staving off political crises. One way for the U.S. to play a more influential role in the region is through the use of partners, such as India. As India is a U.S. strategic partner, a stable democracy, and a growing economic power, a greater Indian presence in the region may be beneficial for the U.S. interests. India is refurbishing a former Soviet air base in Tajikistan, which is intended as part of an effort to contribute to stability in Afghanistan and to battle Islamist 
terrorism in Central Asia. Both goals are shared by the United States. India can also lend its support to increasing export options for Central Asian oil and natural gas. In addition to helping to break up the Russian natural gas transit monopoly, this would contribute to economic growth, stability, and improved relations between the pipeline transit countries of India, Pakistan, and Afghanistan, which is in the U.S. interests. It is vital that the U.S. maintain and expand a multifaceted presence in Central Asia. The benefits of the U.S. involvement accrue to both sides: the U.S. can protect its security, military, and geopolitical interests and its energy access while helping to promote the development of democracy and civil society in Central Asia. The developing nations of Eurasia can gain access to the much-needed U.S. investment, security assistance, and global integration above and beyond what they are offered by Russia, China, India, and Iran.

\section{Challenges to the U.S. Energy Interests}

A real challenge in promoting the U.S. energy interests worldwide, including in Central Asia, is the high level of corruption in the state-run energy sectors. Some argue that it would be unwise to sacrifice the U.S. energy and security interests because of difficulty in dealing with regimes that do not share the U.S. values. After all, such regimes are the majority among the oil producers. This is a real challenge to the U.S. policymakers. The U.S. experience with criticism of President Islam Karimov of Uzbekistan over the Andijon massacre, in which the Uzbek military opened fire on armed Islamists as well as civilian protestors, is a case in point. This criticism provoked a harsh Uzbek response that resulted in the loss of both a strategic relationship and the U.S. access to the Karshi-Khanabad air bases ${ }^{5}$. This incident can be seen as a valuable learning opportunity for the U.S. policymakers. Intransigence on the issue of democracy development to the exclusion of other U.S. national interests and priorities has not served the U.S. well in Uzbekistan and has led to an overreliance on the Manas International Airport air base in Kyrgyzstan, which comes with an annual price tag in the $\$ 150$ million range.

5. Karshi-Khanabad is an air base in southeastern Uzbekistan, just east of Karshi. It is home to the 60th Separate Mixed Aviation Brigade of the Uzbek Air Force. 
Given the high cost of human rights priorities, a more relevant question in this climate of energy insecurity and tight energy markets would be: "How can the U.S. successfully balance its security, energy, and human rights priorities in a way that maximizes the U.S. interests?" The U.S. needs to stay engaged with the leaders of most states and with elites, political parties, and the people in Central Asia. Only through this sort of engagement will the U.S. begin to rebuild its former status as friend and a model to these countries, as opposed to an external superpower determined to topple regimes in the region. The task of developing Azeri or Kazakh mineral riches, however, requires a lot more than simply opening doors for the U.S. oil companies to the producer countries. The Caspian is a treacherous territory for doing oil business. Most of its oil deposits are under water, and the actual legal status of the Caspian Sea has yet to be defined 21 years after the collapse of the Soviet Union. In fact, the Caspian is considered a sea by some countries and a lake by many others. An April 2002 conference of the presidents of the five littoral states, meant to divide up the sea's surface and bed, ended in acrimony. Ownership of a number of oil fields is being disputed - Azerbaijan and Turkmenistan went to court over one such field, and in summer of 2001 the Iranian Navy forced a British Petroleum exploration vessel from a disputed area near the Azeri-Iranian border. Producers are understandably shy about investing millions of dollars into wells that could be expropriated or destroyed in an attack.

\section{Policy Goals}

By staying engaged and persistent, the U.S. may be able to make serious progress on achieving its objectives in Central Asia, which include:

- Resolution of intra-regional conflicts and support of political, economic, and security cooperation in the interest of fostering regional stability and economic interdependence;

- Promotion of transparent, law-based economic development based on market principles;

- Assistance to the development of communications, transportation, health, and human services infrastructure; 
- Protection and promotion of the U.S. businesses and investments;

- Promotion of an independent, transparent, and responsible government in each state; and

- Development and protection of human rights, tolerance, and pluralism.

\section{What Should Be Done}

To achieve these goals, the U.S. National Security Council should coordinate activities by the U.S. State Department, Department of Defense, Department of Energy, and other departments to pursue the following policies:

1. Continue to encourage the governments of India, China, and Pakistan to create alternatives to the Russian energy transit monopoly by establishing new energy transit routes (pipelines, shipping lines, and railroads) that head west and, in some cases, east and south.

2. Encourage multinational corporations to diversify energy transit routes to mitigate risk. This is a common interest of the U.S., members of the EU, and China.

3. Develop closer ties to Central Asian states by stressing mutual gains from Western investment, military presence, and security cooperation. Specifically,

- Assist economic and legislative reform in order to attract and protect foreign investors and spur economic growth;

- Coordinate reform activities with international financial institutions and programs administered by the members of the EU, such as the British Know-How Fund;

- Strengthen military-to-military, intelligence, anti-terrorism, and law enforcement relationships; and

- Enhance democratic and civil society institutions through programs administered by the National Endowment of Democracy and non-governmental organizations. 
4. Adopt a nuanced approach to states whose leaders are not amenable to cooperation with the U.S., specifically Turkmenistan and Uzbekistan. Specifically,

- Emphasize common security interests, especially fighting Islamist terrorism, and pursue military-to-military cooperation when it is in the U.S. interests;

- Facilitate energy cooperation, including private-sector investment projects and transit (pipeline) projects that enhance hydrocarbon supply to global markets;

- Support secular or moderate Islamic democratic opposition parties or figures (who necessarily must be opposed to any jihadi or terrorist-extremist sponsor states or organizations) without openly pursuing regime change;

- Examine and encourage possibilities for stability-enhancing dialogue between existing regimes and democratic and moderate Islamic opposition groups to facilitate the opening of the political system;

- Engage, where necessary, in public information campaigns to criticize existing leaderships and expose their abuses; and

- Guard against Islamist backlash by supporting recognition and dialogue between existing regimes and secular opposition groups and other legitimate, non-destabilizing political actors.

\section{Conclusion}

The U.S. and Central Asian political, economic and security interests are not mutually exclusive and may be better achieved through cooperation than through confrontation. Development and security of supply and transit is one such common interest that needs to be cultivated. Not seeing eye-to-eye on every issue should not prevent states from working together to attain shared goals. Even if relations between the U.S. and Central Asian states or Russia are at a post-Soviet low point, common interests such as energy development, fighting terrorism and limiting nuclear non- 
proliferation should be pursued and cultivated. The U.S. involvement and assistance contribute to the economic, political, social and security development of the states of Central Asia. The United States should remain as engaged as possible in the region. Given recent tensions concerning values, preferred economic models and political systems, such engagement will be complex. Continuous dialogue with regional actors, as well as with Russia, China, the European Union and its key members, Japan and India, is required to coordinate policies and prevent crises. This will demand give-and-take on both sides and the U.S. may find that getting concessions requires making concessions. As the greater and more influential power the U.S. may find it necessary at times to make the first move.

\section{References}

Ebel, E. R. 1996. The Dynamics of Caspian Sea Resources, paper presented to a Conference on Conflict Resolution, organized by the Institute of International Relations, Panteion University, on Corfu on 30-31 August, p.116

Ebel, E. R. 1995. Petroleum, A New Factor in the Black Sea Security Context, unpublished paper presented at a conference on Security and the Black Sea, held in Varna, Bulgaria, 9-10 May, p. 120

Forsythe, R. 1996. The Politics of Oil in the Caucasus and Central Asia, Adelphi Paper

Gray, C. S. 1977. The Geopolitics of the Nuclear Era: Heartland, Rimlands, and the Technological Revolution. New York: Crane, Russak and Co.

Hill, F. 1997. Pipeline Politics, Russo-Turkish Competition and Geopolitics in the Eastern Mediterranean in Security and Cooperation in the Eastern Mediterranean. Cyprus: Intercollege Press 
Tolf, W. R. 1976. The Russian Rockefellers. Stanford: Hoover Institution Press

Yergin, D. 1991. The Prize: The Epic Quest for Oil, Money and Power. New York: Simon \& Schuster 